\title{
Analisis Penerapan Unggah Ungguh Bahasa Jawa dalam Nilai Sopan Santun
}

\author{
Chusnul Chotimah ${ }^{1 *}$, Mei Fita Asri Untari ${ }^{2}$, M. Arief Budiman ${ }^{3}$
}

${ }^{123}$ Jurusan Pendidikan Guru Sekolah Dasar, Universitas PGRI Semarang, Indonesia

\author{
A R T I C LEINFO \\ Article history: \\ Received 18 February \\ 2019 \\ Received in revised form \\ 20 March 2019 \\ Accepted 20 April 2019 \\ Available online 20 May \\ 2019 \\ Kata Kunci: \\ Bahasa Jawa, Penerapan \\ Unggah-Ungguh, , Nilai \\ Sopan Santun \\ Keywords: \\ Java Language, Application- \\ Ungguh Upload, Value \\ Manners
}

\begin{abstract}
A B S T R A K
Latar belakang yang mendorong penelitian ini adalah kurangnya penerapan unggah-ungguh bahasa Jawa dalam membentuk karakter sopan santun. Peserta didik yang belum mencerminkan karakter sopan santun dalam berperilaku. Permasalahan dalam penelitian ini adalah bagaimana penerapan unggah-ungguh bahasa Jawa dalam nilai sopan santun di SD Muhammadiyah 11 Semarang. Penelitian ini bertujuan untuk menganalisis dan mengetahui nilai karakter sopan santun dalam unggah-ungguh bahasa Jawa pada kelas V SD Muhammadiyah 11 Semarang. Penelitian ini menggunakan deskriptif kualitatif yaitu penelitian yang menggambarkan peristiwa atau fenomena dengan data-data yang berbentuk infoemasi atau kata-kata. Lokasi penelitian di SD Muhammadiyah 11 Semarang Kelas V Semester 2. Data bersumber dari kata-kata hasil penelitian. Metode pengumpulan data : observasi, angket (kuesioner) dan dokumentasi. Teknik analisis data : pengumpulan data, keabsahan data, penyajian data dan penarikan kesimpulan.
\end{abstract}

\section{A B S T R A C T}

Background push this study is the lack of application-ungguh upload Java language in shaping the character of manners. Learners who do not yet reflect the character manners of behaving. The problem in this research is how the application-ungguh upload Java language in the value of manners in SD Muhammadiyah 11 Semarang. This study aimed to analyze and determine the character values decorum in-ungguh upload Java language in class V SD Muhammadiyah 11 Semarang. This study used a qualitative descriptive research that describe the events or phenomena with data in the form of infoemasi or words. The research location in SD Muhammadiyah 11 Semarang Class V Semester 2. Data derived from the words of research results. Methods of data collection: observation, questionnaires (questionnaires) and documentation. Data analysis techniques: data collection, data authenticity, data presentation and conclusion.

\footnotetext{
${ }^{1}$ Corresponding author.

E-mail addresses: chusnul15chotimah@gmail.com (Chusnul Chotimah)
} 


\section{Pendahuluan}

Pendidikan merupakan suatu bentuk usaha sadar yang dilakukan oleh manusia yang bertujuan mempengaruhi pola pikir untuk menambah pengetahuan dan wawasan secara terperinci. Pendidikan dapat mencerminkan tingkat kualitas bangsa atau negara yang terjamin dan berpotensi. Dengan adanya pendidikan dapat mencerminkan kualitas seseorang di dalam masyarakat. Pendidikan dapat mengubah pola pemikiran seseorang menjadi berwawasan lebih luas. Pendidikan merupakan suatu bentuk usaha seorang pendidik yang bertujuan untuk memberikan bekal ilmu dan pengetahuan untuk siswa yang nantinya akan digunakan di masa yang akan datang. Menurut Bermawi (2016) Pendidikan sebagai sumber daya insani sepatutnya mendapat perhatian secara terus menerus dalam upaya peningkatan mutu. Peningkatan mutu pendidikan berarti peningkatan kualitas sumber daya manusia. Maka perlu dilakukan pembaruan dalam bidang pendidikan dari waktu ke waktu tanpa berhenti. Pendidikan membantu manusia mengembangkan potensi. Salah satunya adalah hidup rukun disekolah. Menurut Laksana (2015) Pendidikan merupakan upaya yang terencana dalam proses pembimbingan dan pembelajaran bagi individu agar berkembang dan tumbuh menjadi manusia yang mandiri, bertanggungjawab, kreatif, berilmu, sehat, dan berakhlak mulia, baik dilihat dari aspek jasmani maupun ruhani. Manusia yang berakhlak mulia, yang memiliki moralitas tinggi sangat dituntut untuk dibentuk atau dibangun. Bangsa Indonesia tidak hanya sekedar memberikan makna akan pentingnya pendidikan, melainkan bagaimana bangsa Indonesia mampu merealisasikan konsep pendidikan dengan cara pembinaan, pelatihan dan pemberdayaan SDM Indonesia secara berkelanjutan dan merata. Menurut Omeri (2015) Pendidikan nasional berfungsi mengembangkan kemampuan dan membentuk watak serta peradaban bangsa yang bermartabat dalam rangka mencerdaskan kehidupan bangsa, yang bertujuan untuk berkembangnya potensi peserta didik agar menjadi manusia yang beriman dan bertakwa kepada Tuhan Yang Maha Esa, berakhlak mulia, sehat, berilmu, cakap, kreatif, mandiri, dan menjadi warga negara yang demokratis serta bertanggung jawab.Pendidikan merupakan bagian penting dari kehidupan manusia yang tak pernah bisa ditinggalkan. Pendidikan bukanlah proses yang diorganisasi secara teratur, terencana, dan menggunakan metode-metode yang dipelajari serta berdasarkan aturan-aturan yang telah disepakati mekanisme penyelenggaraan oleh suatu komunitas suatu masyarakat (Negara), melainkan lebih merupakan bagian dari kehidupan yang memang telah berjalan sejak manusia itu ada. Menurut Nurkholis (2013) Pendidikan lebih dari sekedar pengajaran, yang dapat dikatakan sebagai suatu proses transfer ilmu, transformasi nilai, dan pembentukan kepribadian dengan segala aspek yang dicakupnya. Dengan demikian pengajaran lebih berorientasi pada pembentukan spesialis atau bidangbidang tertentu, oleh karena itu perhatian dan minatnya lebih bersifat teknis. Pendidikan merupakan suatu proses yang diperlukan untuk mendapatkan keseimbangan dan kesempurnaan dalam perkembangan individu maupun masyarakat. Penekanan pendidikan dibanding dengan pengajaran terletak pada pembentukan kesadaran dan kepribadian individu atau masyarakat di samping transfer ilmu dan keahlian. Dengan proses semacam ini suatu bangsa atau negara dapat mewariskan nilai-nilai keagamaan, kebudayaan, pemikiran dan keahlian kepada generasi berikutnya, sehingga mereka betul-betul siap menyongsong masa depan kehidupan bangsa dan negara yang lebih cerah. Pendidikan juga merupakan sebuah aktifitas yang memiliki maksud atau tujuan tertentu yang diarahkan untuk mengembangkan potensi yang dimiliki manusia baik sebagai manusia ataupun sebagai masyarakat dengan sepenuhnya.

Dengan adanya pendidikan dapat mewujudkan sumber daya manusia yang berkualitas di dalam masyarkat ataupun negara. Dengan hal tersebut negara dapat terlihat dengan jelas kualitas sumber daya manusianya. Jika tingkat pendidikan berkualitas dan berbobot dapat diketahui bahwa sumber daya manusia di negara tersebut dapat dikatakan maju dan baik sebaliknya apabila tingkat pendidikan kurang memumpuni maka sumber daya manusia yang dihasilkan juga rendah. Pendidikan harus dilakukan dengan penuh rasa tanggung jawab dan keikhlasan diri, sehingga hasil yang disampaikan mampu merubah pola pikir manusia menjadi lebih berkembang dan dapat bersaing di masyarakat maupun negara. Fungsi dari pendidikan itu sendiri adalah untuk memberikan pengetahuan yang lebih tinggi untuk bekal di masa yang akan datang.

Seperti yang tercantum dalam Pusat Bahasa Departemen Pendidikan Nasional. 2002 : 263, menyatakan bahwa : "Pendidikan adalah proses pengubahan sikap dan tatalaku seseorang atau kelompok orang dalam usaha mendewasakan manusia melalui upaya pengajaran dan pelatihan, proses, cara, perbuatan mendidik".

Dalam tujuan tersebut yang perlu kita lakukan dalam mendidik siswa salah satunya dengan cara melatih perbuatan anak. Dengan cara tersebut anak dapat dibiasakan dalam kehidupan sehari-hari. Misalkan saja dalam penerapan berbicara terhadap orang yang lebih tua. Sebagai seorang anak yang usianya terbilang masih kecil atau orang dewasa jika berbicara atau berkomunikasi dengan orang yang lebih tua, sebaiknya menggunakan kosakata yang baku agar lebih sopan untuk menghormati. 
Mengajarkan dan menanamkan nilai sopan santun pada siswa dengan berlandaskan nilai budaya lokal, salah satunya dapat melalui pengenalan dan pendidikan berkarakter sejak usia dini. Menerapkan nilai sopan santun dikehidupan sehari-hari merupakan salah satu cara untuk membiasakan anak agar bisa bertingkah laku dengan baik dan sopan.

Menurut Wulan (2013) Bahasa merupakan ssalah satu kebudayaan yang diciptakan dan digunakan oleh manusia itu sendiri sebagai alat komunikasi. Bahasa juga sebagai alat ekspresi diri dan sebagai alat komunikasi sekaligus pula merupakan alat untuk menunjukkan identitas diri. Melalui bahasa, manusia dapat menunjukkan sudut pandangnya, pemahaman tentang suatu hal, asal usul bangsa dan negara, pendidikan, dan bahkan sifat-sifat yang melekat pada dirinya. Bahasa menjadi cermin diri, baik sebagai bangsa maupun sebagai diri sendiri. Bahasa merupakan salah satu alat terpenting untuk berkomunikasi secara efektif agar maksud pesan yang diutarakan dapat tersampaikan dengan jelas. Bahasa sebagai icon budaya dipenjuru daerah bahkan negara manapun. Bahasa sebagai alat kebutuhan sehari-hari bagi manusia untuk melangsungkan kehidupan. Di Indonesia sendiri dari berbagai pulau mempunyai banyak suku dan budaya yang beraneka ragam. Sehingga beraneka ragam juga bahasa yang dihasilkan. Salah satunya di Pulau Jawa, di Pulau Jawa mayoritas masyarkatnya dapat menguasai bahasa daerah yaitu bahasa Jawa dengan baik. Bahasa Jawa sebagai alat pengantar komunikasi bagi masyarakat Jawa. Bahasa Jawa sendiri memiliki tingkatan kosakata baik yang digunakan untuk berbicara kepada orang yang lebih tua.

Menurut Sudiatmanto (2016) Sebagai salah satu mata pelajaran penting yang berguna untuk melestarikan kebudayaan daerah ialah Bahasa Jawa. Mata pelajaran Bahasa Jawa dikembangkan agar ciri khas masyarakat suku Jawa dapat lestari dan tentunya akan berguna dalam menopang kebudayaan nasional yang beraneka ragam, sebab sudah disadari bersama bahwa kebudayaan daerah merupakan akar dari kebudayaan nasional. Menurut Rumidjan (2016) Pembelajaran Bahasa Jawa diharapkan dapat membantu peserta didik mengenal dirinya, lingkungannya, menerapkan dalam tata krama budayanya, menghargai potensi bangsanya, sehingga mampu mengemukakan gagasan dan perasaan, berpartisipasi dalam masyarakat, dan dapat menemukan serta menggunakan kemampuan analisis, imajinatif dalam dirinya. Bahasa Jawa di Sekolah, keluarga, dan masyarakat. Pemahaman siswa terhadap kosa kata Bahasa Jawa sangat minim. Pengetahuan dan penerapan unggah-ungguh sangat sulit dan kaku. Banyak guru yang kurang memahami dan menguasai materi, karena tidak didukung oleh latar pendidikan bahasa Jawa.Teladan dari guru untuk ditiru siswa masih kurang. Fasilitas media maupun alat peraga yang digunakan masih sedikit/kurang. Kurangnya perhatian beberapa pihak yang menganggap Bahasa Jawa adalah mata pelajaran yang tidak penting. Pembelajaran belum memberi kontribusi berarti dalam perubahan pola tingkah laku negatif menjadi positif. Pembelajaran Bahasa Jawa belum dikemas dalam skenario yang mencerminkan penanaman pendidikan watak dan pekerti bangsa. Bahasa Jawa merupakan salah satu warisan dari nenek moyang di Indonesia. Dengan pernyataan Sudaryanto (1992:9) menerangkan bahwa Bahasa Jawa sebagaimana bahasa pada umumnya ada untuk mengungkapkan segala sesuatu yang menjadi kekayaan jiwa penutur-penuturnya untuk disampaikan kepada pendengar mitra wicaranya. Dengan pernyataan hal tersebut menjelaskan bahwa Bahasa Jawa merupakan salah satu kekayaan bahasa yang ada. Bahasa Jawa mempunyai cara atau dialek tersendiri untuk menyampaikan maksud atau pesan yang akan disampaikan kepada informan sebagaimana tujuan bahasa pada umumnya. Menurut Puspitoningruma (2018) Fungsi bahasa Jawa adalah sebagai pesan untuk menyampaikan pesan atau isi informasi oleh anggota masyarakat yang saling berinteraksi dan bekerja sama dalam tataran pergaulan masyarakat lingkung kebudayaan dan peradaban Jawa. Bahasa Jawa sebagai bahasa daerah yang saat ini masih digunakan oleh masyarakat yang ada di Jawa Tengah, Jawa Timur, DIY, dan masyarakat Jawa yang berada di luar Pulau Jawa.

Penggunaan Bahasa Jawa dipengaruhi oleh berbagai faktor, seperti: umur, golongan, dan status sosial. Apabila kita berbicara dengan teman sebaya menggunakan bahasa Jawa Ngoko. Apabila kita sedang berbicara dengan orang yang lebih tua dari kita baiknya menggunakan bahasa Jawa Krama sebagai tanda menghormati. Pengaruh status sosial juga dapat mempengaruhi cara berbicara pada Bahasa Jawa, karena itu sebagai tanda menghormati dan menhargai terhadap orang yang diajak bicara. Penggunaan bahasa Jawa baik dalam situasi formal maupun non formal harus disesuaikan dengan situasi dan kondisi yang ada. Misalkan saat siswa bertanya kepada gurunya :

"Bu, buka buku halaman piro?"

"Bu, buka buku halaman berapa?"

(Sumber : ucapan seorang siswa yang bertanya untuk membuka buku halaman berapa kepada gurunya) 
Kata piro yang diucupakan tidak tepat, karena kata piro termasuk bahasa Jawa Ngoko. Akan lebih tepat jika diganti dengan kata pinten, yang berarti 'berapa' namun tingkat kosakatanya lebih sopan untuk diucapkan kepada orang yang lebih tua. Maksud dan ucapan siswa tersebut kurang baik, karena masih menggunakan bahasa Jawa Ngoko, yang seharusnya digunakan untuk berkomunikasi dengan teman sebaya. Anak-anak usia sekolah dasar mungkin terbiasa di lingkungan rumah menggunakan bahasa Jawa Ngoko, karena anak-anak lebih banyak menghabiskan waktunya untuk bermain dengan teman-teman seusianya.

Dengan banyaknya fenomena yang terjadi saat ini dimana anak yang lebih muda tidak bisa menghormati orang yang lebih tua. Misalkan saja saat anak yang berusia remaja atau dewasa saat berbicara dengan orang tuanya masih kurang sopan karena menggunakan bahasa Ngoko bukan bahasa Krama. Hal tersebut diartikan bahwa anak belum dapat menerapkan penggunaan bahasa yang tepat atau kemungkinan anak belum terbiasa menggunakan bahasa yang lebih sopan dikehidupan sehari-harinya jadi merasa kagok.

Berdasarkan observasi peneliti saat pelaksanaan magang di sekolah dasar, peneliti seringkali masih menjumpai anak didik yang masih menggunakan bahasa Jawa Ngoko saat berbicara dengan orang yang lebih tua, baik itu orang tuanya ataupun gurunya. Ada juga yang sopan saat berbicara dengan orang tuanya yaitu menggunakan bahasa Indonesia saat berbicara. Namun akan lebih baik lagi jika anak didik diajarkan untuk bisa berbicara dengan bahasa Jawa Krama agara dapat menghormati orang yang lebih tua. Selain itu juga dapat melestarikan budaya di Jawa, yaitu menggunakan bahasa Jawa Krama untuk menunjang budaya sopan santun atau dalam bahasa Jawa disebut unggah-ungguh.

Berdasarkan hasil pemaparan permasalahan di atas, maka peneliti akan melakukan penelitian mengenai peranan unggah-ungguh bahasa Jawa dalam sikap sopan santun dengan judul "Analisis Penerapan Unggah-Ungguh Bahasa Jawa dalam Nilai Sopan Santun di Lingkungan SD Muhammadiyah 11 Semarang"

\section{Metode}

Sugiyono (2016: 9) mengemukakan bahwa metode penelitian kualitatif merupakan metode penelitian yang didasari oleh filsafah postpositivisme, yang digunakan meneliti pada keadaan objek yang bersifat alamiah, dimana penelti bertindak sebagai pemegang kunci, teknik pengumpulan data dilakukan secara triangulasi, analisis data bersifat kulitatif dan hasil dari penelitian lebih terfokuskan kepa da makna dari pada generalisasi. Dengan menggunakan pendakatan kualitatif dapat bertujuan untuk memahami peranan unggah-ungguh bahasa Jawa dalam lingkungan sekolah dasar dan faktor yang mempengaruhinya.

Penggunaan pendekatan kualitatif dipilih dengan tujuan untuk memahami peran dari penggunaan unggah-ungguh bahasa Jawa dalam lingkungan sekilah dasar dan latar belakang dari permasalahan.

Lokasi penelitian adalah tempat dimana penelitian berlangsung. Penelitian ini dilaksanakan di SD Muhammadiyah 11 Semarang dengan sasaran penelitian yaitu siswa kelas V SD Muhammadiyah 11 Semarang. Karena di SD tersebut ditemukan permasalahan penerapan unggah ungguh bahasa jawa dalam nilai sopan santun.

Penelitian ini menggunakan data berupa wawancara, hasil observasi dan hasil dokumentasi. Data yang sudah didapatkan akan diolah dan didefinisikan sesuai tujuan penelitian.

Penelitian ini menggunakan sumber data yang didapatkan dari hasil observasi, wawancara, dan dokumentasi dari objek yang diteliti. Dalam penelitian ini objek utama yang akan diteliti yaitu siswa kelas V SD Muhammadiyah 11 Semarang. Dan peneliti memperoleh data dari guru dan orang tua yang ikut serta di dalam penelitian ini.

Instrumen yang digunakan penelitian ini adalah dengan lembar wawancara dan lembar kuesioner (angket). Lembar wawancara digunakan untuk mengetahui pendapat atau jawaban dari guru, siswa dan orang tua mengenai penerapan unggah-ungguh bahasa Jawa dalam nilai sopan santun. Lembar kuesioner digunakan untuk mengetahui pendapat dan respon mengenai penggunaan bahasa Jawa dalam kehidupan sehari-hari di rumah maupun di sekolah.

Dalam penelitian ini menggunakan penggumpulan data berupa observasi, wawancara, angket dan dokumentasi.

a. Observasi

Observasi (observation) atau pengamatan merupakan suatu teknik atau cara mengumpulkan data dengan jalan mengadakan pengamatan terhadap kegiatan yang sedang berlangsung, Sugiyono (2016:220). Creswell $(2010,267)$ berpendapat observasi merupakan yang di dalamnya peneliti langsung turun ke lapangan untuk mengamati perilaku dan aktivitas individu-individu di lokasi penelitian. Observasi dilakukan di SD Muhammadiyah 11 Semarang dengan objek siswa kelas V. Observasi dilakukan dengan wawancara dengan siswa kelas $\mathrm{V}$ tentang penggunaan unggah-ungguh bahasa Jawa. 


\section{b. Wawancara}

Wawancara atau interview merupakan salah satu bentuk teknik pengumpulan data yang banyak digunakan dalam penelitian deskriptif kualitatif dan deskriptif kuantitatif. Wawancara dilakukan secara lisan dalam pertemuan tatap muka secara individual (Sukmadinata, 2016:216).

Dalam penelitian ini obyek yang akan diwawanacara adalah guru, siswa dan orang tua sebagai narasumber atau sumber data yang akan dianalisis. Pada pelaksanaan wawancara dengan siswa dan guru dilakukan di sekolah. Saat wawancara dengan orang tua siswa dilaksanakan di rumah masing-masing. c. Angket

Angket atau kuesioner merupakan suatu teknik atau cara pengumpulan data secara tidak langsung (peneliti tidak langsung bertanya-jawab dengan responden). Instrumen atau alat pengumpulan datanya juga disebut angket yang berisi sejumlah pertanyaan atau pernyataan yang harus dijawab atau direspon oleh responden (Sukmadinata, 2016:218).

Dalam penelitian ini peneliti memberikan angket kepada siswa kelas V SD Muhammadiyah 11 Semarang, yang setiap siswa diberikan lembar kuesioner. Kumpulan dari beberapa data yang sudah didapatkan akan digabung dan kemudian dianalisis untuk diambil kesimpulan akhir berupa deskripsi kualitatif. Peneliti memberikan angket kepada siswa, guru dan orang tua untuk mengisi beberapa kuosioner yang diberikan dari peneliti.

d. Dokumentasi

Studi dokumenter merupakan suatu teknik pengumpulan data dengan menghimpun dan menganalisis dokumen-dokumen, baik dokumen tertulis, gambar maupun elektronik, Sukamdinata (2016:221). Dokumentasi yang didapat adalah foto dan video dari pelakasanaan penelitian.

\section{Hasil dan Pembahasan}

Data dari penelitian ini adalah sikap sopan santun dalam unggah-ungguh bahasa Jawa. Sikap sopan santun dalam bahasa Jawa pada zaman sekarang sangat berkurang. Karena faktor perkembangan zaman dan teknologi semakin maju membuat akses untuk bersosialisasi semakin terhambat. Sekarang anak pada usia Sekolah Dasar mayoritas sudah mempunyai alat komunikasi (handphone), bahkan alat telekomunikasi tersebut dapat digunakan oleh anak dibawah 6 tahun. Hal tersebut yang dapat memberikan dampak buruk bagi psikologi anak.

Dari hasil penelitian yang dilakukan dapat dipaparkan bahwa kebanyakan siswa menggunakan bahasa Jawa dalam berkomunikasi dengan jumlah presentase 92,37 \%, sedangkan pada presntase 7,69 \% siswa tidak menggunakan bahasa Jawa dalam berkomunikasi melainkan menggunakan bahasa Indonesia. Pada opsi pernyataan kedua siswa lebih nyaman menggunakan bahasa Indonesia dengan presentase $61,53 \%$, dibandingkan menggunakan bahasa Jawa dengan jumlah presentase 38,46\%. Siswa lebih lancar berkomunikasi menggunakan bahasa Indonesia dengan ditunjukkan pada presentase dengan jumlah $68,23 \%$, dibandingkan menggunakan bahasa Jawa yang hanya 30,76 \%. Dengan kemungkinan daerah tempat tinggal yang berada di kota membuat cara berkomunikasi menyesuaikan dengan lingkungan. Pada pernyataan siswa tidak bisa berbicara menggunakan bahasa Jawa dengan maksud bahasa Jawa Krama. Siswa belum dapat menggunakan bahasa Jawa yang baik dan sopan dengan presentase 84,61 \%, dengan perbandingan yang dapat menggunakan bahasa Jawa Krama dengan baik hanya 15,38 \%. Dengan penjelasan bahwa siswa belum banyak mengetahui kosakata mengenai bahasa Jawa terutama bahasa Krama. Dengan presentase sebanyak 69,23 \% siswa tidak mengetahui kosakata bahasa Jawa. Dan sekitar 30,76 \% siswa mengetahui tentang kosakata bahsa Jawa. Siswa mengetahui kosakata bahasa Krama dengan keterbatasan kata, misalnya kata-kata singkat seperti nggih, mboten, dereng, dalem, dan sampun. Dapat dijelaskan dengan presentase perolehan pernyataan siswa bisa bahasa Krama saat berbicara dengan orang yang lebih tua sebanyak 69,23 \%. Disini yang dimaksud siswa adalah bahasa-bahasa seperti kata nggih, mboten, dereng, dalem, dan sampun. Dan yang tidak bisa menggunakan bahasa Krama dalam berbicara dengan orang yang lebih tua dengan presentase 30,76\%. Siswa dapat menjawab pertanyaan dari orang tua menggunakan bahasa Krama dengan jumlah 84,61 \% dan yang tidak bisa menajawab pertanyaan menggunakan bahasa Krama sejumlah 15,38 \%.

Dalam pernyataan siswa menggunakan bahasa Ngoko saat berbicara dengan orang tua sebanyak $61,53 \%$ siswa memilih tidak, dan 38,46 \% siswa memilih ya. Hal tersebut dapat dinyatakan bahwa siswa belum dapat menguasai bahasa Jawa dengan baik terutama bahasa Jawa Krama. Dapat disebabkan juga siswa menggunakan bahasa Indonesia saat berkomunikasi dengan orang tuanya. Pada pernyataan siswa terkadang bersikap sopan dengan orang tuanya sebanyak 84,61 \% siswa memilih iya dan sebanyak 15,38 \% siswa memilih tidak. Dan pada pernyataan selanjutnya yang hampir sama yaitu siwa selalu bersikap sopan dengan orang tuanya sebanyak 92,3\% memilih jawaban iya dan sebanyak 7,69 \% memilih siswa tidak. Dengan selisih jumlah perolehan presentase yang sedikit dapat dihasilkan bahwa siswa dapat 
bersikap sopan dengan orang tuanya. Pada pernyataan siswa selalu membantah saat orang tua berbicara, dengan bahasa yang kasar dapat dihasilkan siswa yang memilih iya sebanyak 7,69 \% dan siswa yang memilih tidak sebanyak 92,3 \%. Dengan penjelasan masih terdapat siswa yang membantah dengan bahasa yang kasar saat orang tua berbicara. Hal tersebut dapat disebabkan peran orang tua dan faktor lingkungan.

Mengenai makna unggah-ungguh bahasa Jawa banyak siswa sudah mengerti sebanyak 69,23\% siswa yang memilih iya dan 30,76 \% siswa yang memilih tidak. Siswa mengerti makna unggah-ungguh bahasa Jawa dalam penerapan di kehidupan sehari-hari sebanyak 61,53 \% sedangkan sebanyak 38,76 \% siswa belum dapat menerapkan unggah-ungguh dalam kehidupan sehari-hari. Hal tersebut dapat diutarakan bahwa masih terdapat anak yang belum mengeri makna unggah-ungguh karena keterbatasan pembelajaran di sekolah mengenai unggah-ungguh bahasa Jawa. Dengan sisi lain siswa selalu bersalaman dengan mencium tangan kepada oarang yang lebih tua dengan akumulasi $100 \%$. Artinya secara tidak langsung kurang lebih anak sudah mengerti makna unggah-ungguh dengan cara mencium tangan orang yang lebih tua ketika bersalaman sebagai bentuk rasa menghormati.

Pernyataan selanjutnya yaitu, siswa selalu bersikap sopan dan santun kepada orang yang lebih tua sebanyak 92,3\% siswa memilih iya sedangkan 7,69\% siswa memilih tidak. Jika dapat diakumulasikan dalam bentuk angka riil terdapat satu siswa yang belum memperhatikan sikap sopan dan santun kepada orang yang lebih tua. Dan dalam pernyataan yang hampir sama yaitu mengenai siswa mengerti makna sopan santun dalam kehidupan sehari-hari. Dapat dihitung sebanyak 92,3 \% siswa memilih iya dan 7,69 siswa memilih tidak. Dengan pernyataan yang saling berkaitan. Selain itu juga terdapat akumulasi yang sama dimana terdapat 92,3\% siswa memilih iya dan sejumlah 7,69\% siswa memilih tidak. Dengan pernyataan siswa selalu berjalan menunduk ketika melewati orang yang lebih tua. Namun dalam pernyataan siswa selalu mengucapkan kata "permisi atau amit" saat berjalan melewati orang yang lebih tua dengan akumulasi sebesar 100 \% yang memilih jawaban iya. Dari beberapa masalah tersebut dapat diketahui bahwa siswa saat berjalan melewati orang yang lebih tua hanya mengucapkan kata "permisi atau amit" saja tanpa berjalan agak menunduk.

Pemahaman siswa dalam penggunaan bahasa Jawa Ngoko dan bahasa Jawa Krama sebesar 76,92 $\%$ siswa menyatakan iya, dalam arti siswa sudah paham penggunaannya seperti saat ditanya orang tuanya "Nang, sampun maem dereng ?", siswa kebanyakan akan menjawab "sampun atau dereng". Dengan hal tersebut siswa sudah dapat menerapkan bahasa Krama terhadap orang tuanya. Sedangkan sebanyak $23,07 \%$ menjawab tidak, artinya siswa belum paham penggunaan bahasa Jawa Ngoko dan bahasa Jawa Krama.

Selanjutnya dalam pernyataan siswa bisa menerapkan bahasa Jawa Krama dalam kehidupan sehari-hari sebanyak 69,53 \% siswa memilih iya sedangkan 30,76 \% siswa memilih tidak. Dikarenakan memiliki beberapa faktor yang dapat mempengaruhi penerapan bahasa Jawa Krama dalam berkomunikasi misalnya dalam faktor keluarga yaitu kebiasaan orang tua dalam memakai bahasa Indonesia dalam berbicara dalam lingkungan keluarga. Selain itu juga penggunaan bahasa Indonesia yang mudah dipahami dan diingat. Oleh sebab itu siswa kurang paham saat orang lain berbicara menggunakan bahasa Jawa Krama dengan presentase 61,53 \% siswa menyatakan iya. Yang berarti siswa kurang paham saat orang lain berbicara menggunakan bahasa Jawa Krama. Sedangkan sebanyak 38,46 \% siswa memilih tidak. Yang berarti siswa mengerti dan paham saat orang lain berbicara menggunakan bahasa Jawa Krama.

Siswa kurang mengerti bahasa Jawa Krama sebanyak 53, 84 \% memilih iya. Karena siswa kurang mengerti mengenai kosakata bahasa Jawa, terutama bahasa Jawa Krama. Sedangkan sebanyak 46,15 \% siswa memilih tidak karena ada juga siswa yang sudah mengerti kosakata dalam bahasa Jawa Krama Sedangkan dalam pengolahan kata atau dalam penerapan bahasa Jawa Krama siswa belum dapat menguasainya, sebanyak 69,23 \% siswa memilih iya. Dengan penegertian siswa belum dapat menguasai bahasa Jawa Krama saat berbicara. Seringkali siswa memnggunakan bahasa Indonesia saat berbicara dalam kehidupan sehari-hari. Pada akumulasi presentase 30,76\% siswa memilih tidak, sebab ada siswa yang menggunakan bahasa Jawa Krama saat berbicara dengan orang yang lebih tua. Dengan kebiasaan menggunakan bahasa Jawa Krama siswa tidak merasa kesulitan dalam penerapannya.

Selain dampak baiknya dalam penggunaan bahasa Jawa Krama dalam kehidupan sehari-hari. Juga terdapat dampak buruknya, yaitu siswa masih menggunakan bahasa Jawa Ngoko saat berbicara dengan orang tua dengan presentase 53,84 \% memilih jawaban iya. Sebab dari peran orang tua yang belum mengajarkan tentang bahasa Jawa Krama sejak dini, selain itu juga faktor lingkungan yang terbiasa menggunakan bahasa Jawa Ngoko sehingga siswa menerapkan dalam dirinya. Sedangkan dalam jumlah presentase 46,15 \% siswa memilih tidak. Karena ada siswa yang sudah menggunakan bahasa Jawa Krama dalam berbicara dalam kehidupan sehari-hari. Permasalahan tersebut juga sebanding dengan pernyataan 
siswa tidak bisa menggunakan bahasa Jawa Krama dengan baik saat berbicara dengan orang yang lebih tua dengan jumlah presentase $46,15 \%$ siswa memilih tidak. Karena siswa kebanyaak menggunakan bahasa Jawa Ngoko atau menggunakan bahasa Indonesia saat berkomunikasi dengan orang tuanya atau pun orang yang ada di sekitarnya. Sedangkan sejumlah 53,84 \% siswa memilih tidak, karena siswa sudah dapat menggunakan bahasa Krama dengan baik saat berbicara dengan orang yang lebih tua. Ketika siswa tidak bisa menjawab pertanyaan dalam bahasa Jawa Krama saat ditanya dengan orang yang lebih tua sebanyak 38,46 \% siswa memilih iya. Dengan penjelasan siswa masih merasa kebingungan saat ditanya menggunakan bahasa Jawa Krama. Siswa paham saat ditanya, namun saat ingin menajawab siswa merasa bingung dalam penggunaan kosakata. Daripada itu sebanyak 61,53 \% siswa sudah bisa menjawab pertanyaan dalam bahasa Jawa Krama saat ditanya dengan orang yang lebih tua.

Sehingga penerapan dalam unggah-ungguh bahasa Jawa dalam nilai sopan santun dapat dikatakan cukup baik. Dengan berbagai sumber yang telah diteliti menyatakan bahwa penggunaan bahasa Jawa Krama siswa sudah bisa dengan berbicara kata-kata yang singkat namun dalam penggunaan kata yang berupa kalimat siswa belum dapat menguasai. Selain itu juga dalam kesehariannya siswa lebih banyak menggunakan bahasa Indonesia saat berkomunikasi.

Dari data hasil wawancara yang dilakukan oleh guru dan orang tua dapat diperoleh data bahwa dalam kehidupan sehari-hari siswa atau anak saat berkomunikasi lebih sering menggunakan bahasa Indonesia dan bahasa Jawa. Hal tersebut dapat dipengaruhi oleh orang tua yang terbiasa menggunakan bahasa Indonesia dan belum membiasakan menggunakan bahasa Jawa Krama. Dengan kebiasaan tersebut anak lebih mudah dan paham berkomunikasi menggunakan bahasa Indonesia. Lain daripada hal itu, ada juga faktor yang dapat mempengaruhi yaitu penempatan tempat tinggal yang berada di pusat kota yang dapat memberikan penguatan anak dalam berkomunikasi lebih sering menggunakan bahasa Indonesia.

Berdasarkan tempat tinggal yang berada di kota sangat sulit untuk menerapkan unggah-ungguh bahasa Jawa. Saat berkomunikasi dengan orang yang lebih tua terutama orang tua nya anak lebih sering menggunakan bahasa Indonesia. Namun dalam penerapan sopan santun anak sudah bisa menerapkanya dalam kehidupan di sekolah maupun di rumah misalkan dalam berbicara dengan orang yang lebih tua. Apabila orang tua bertanya menggunakan bahasa Jawa Krama anak dapat menjawab menggunakan bahasa Jawa Krama walaupun hanya sepatah atau dua patah kata, misalnya nggih, sampun, mboten. Seperti anak sudah dapat bersalaman dengan mencium tangan saat dengan orang yang lebih tua. Berjalan agak menunduk dan mengucapkan kata permisi atau amit (dalam bahasa Jawa) saat melewati orang yang lebih tua. Kemudian menjawab pertanyaan menggunakan bahasa Jawa Krama saat merespon pertanyaan dari orang tua. Dari latar belakang orang tua yang berpendidikan belum bisa menjamin anaknya dapat menerapkan unggah-ungguh bahasa Jawa dengan baik dalam kehidupan sehari-hari. Masih terdapat anak mempunyai orang tua dengan latar belakang pendidikan masih menggunakan bahasa Indonesia walaupun sudah dapat menerapkan nilai sopan santun dalam berperilaku.

\section{Simpulan dan Saran}

Berdasarkan dari hasil penelitian dan pembahasan yang telah diuraikan, dapat disimpulkan bahwa terdapat siswa yang dapat menerapkan unggah-ungguh dalam kehidupan sehari-harinya misalkan dalam berkomunikasi siswa sudah menggunakan unggah-ungguh dalam berbicara bahasa Jawa Krama walaupun hanya sebatas kata-kata pendek yang dapat diucapkan dan mereka mengerti. Misalkan mengucapkan kata nggih, mboten, dereng dan sampun. Adapula yang belum mengetahui apa itu unggah-ungguh bahasa Jawa. Kebanyakan siswa dan siswi di rumah maupun di sekolah saat berkomunikasi dengan orang tuanya menggunakan bahasa Indonesia. Karena menurut orang tuanya menggunakan bahasa Indonesia lebih mudah dipahami dan sudah kebiasaan dari lingkungan yang berada di pusat Kota Semarang sehingga tidak memungkiri bahwa mayoritas masyarakatnya banyak menggunakan bahasa Indonesia sebagai alat komunikasi sehar-hari.

Berdasarkan hasil penelitian yang dilakukan melalui wawancara dengan orang tua siswa menyatakan bahwa bagi orang tua yang mempunyai latar belakang seorang pendidik belum tentu anaknya dapat atau menguasai perbendaharaan bahasa Jawa dengan baik. Karena beberapa faktor yang dapat mempengaruhi salah satunya adalah kebiasaan saat berkomunikasi di rumah dan faktor lingkungan sekitar. Yang mana berkomunikasi menggunakan bahasa Indonesia lebih mudah dipahami.

Setelah melaksanakan penelitian di SD Muhammadiyah 11 Semarang, ada beberapa saran yang perlu dikemukakan sebagai berikut : 1) Bagi guru sekolah dasar dapat menerapkan unggah-ungguh bahasa Jawa dalam berkomunikasi dalam kehidupan sehari-hari untuk menambah kosakata siswa dalam berbicara dengan orang yang lebih tua terutama di sekolah dan di rumah. 2) Kepada pihak sekolah sebaiknya dapat menerapkan budaya dalam unggah-ungguh dalam lingkungan sekolah dalam program harian. Sehinggga anak dapat membiasakan berperilaku sopan santun sejak dini dan dapat menerapkan 
dari hasil program sekolah tersebut dalam kehidupannya di lingkungan rumah. 3) Bagi siswa hendaknya dapat lebih giat lagi dalam pembelajaran unggah-ungguh bahasa Jawa. Karena dari tangan siswalah yang dapat melestarikan budaya yang telah lama digunakan. Dengan mengetahui unggah-ungguh Bahasa Jawa siswa dapat membentuk kepribadian yang ramah dan sopan terhadap lingkungan.

\section{Daftar Rujukan}

Bermawi, Yoserizal, Tati Fauziah. 2016. Penerapan Pendekatan Saintifik dalam Pembelajaran di Sekolah Dasar Aceh Besar. Jurnal Pesona Dasar Vol. 2 No. 4 Hal. 63-71. Tersedia Pada : http://www.jurnal.unsyiah.ac.id/PEAR/article/view/7533.

Creswell, W. John. 2010. Reserach Design Pendekatan Kaulitatif, Kuantitatif dan Mixed. Yogyakarta. Pustaka Pelajar.

Laksana, Sigit Dwi. 2015. Urgensi Pendidikan Karakter Bangsa Di Sekolah. M U A D D I B Vol. 05 No. 01 Hal. 167-183. Tersedia Pada http://eprints.umpo.ac.id/1779/2/Kompilasi\%20Artikel\%2052\%204.pdf.

Nurkholis. 2013. Pendidikan dalam Upaya Memajukan Teknologi. Jurnal Kependidikan, Vol. 1 No. 1 Hal. $24-44$

Tersedia

Pada

http://ejournal.iainpurwokerto.ac.id/index.php/jurnalkependidikan/article/view/530.

Omeri, Nopan. 2015. Pentingnya Pendidikan Karakter Dalam Dunia Pendidikan. Manajer Pendidikan, Vol. 9 No. 3 Hal. 464-468. Tersedia Pada https://ejournal.unib.ac.id/index.php/manajerpendidikan/article/download/1145/953.

Pusat Bahasa Departemen Pendidikan Nasional. (2002). Kamus Besar Bahasa Indonesia. Jakarta : Balai Pustaka.

Puspitoningruma, Encil, dan Marista Dwi Rahmayantis. 2018. Bahan Ajar Pacelathon Undha Usuk Basa Jawa Sebagai Penguatan Karakter Tata Krama Berbicara Siswa dalam Mata Pelajaran Muatan Lokal Bahasa Daerah. Kembara: (Jurnal Keilmuan Bahasa, Sastra, dan Pengajarannya) Diterima : 9/April/2018 Vol. 4 No. 1 Hal. 21-34. Tersedia Pada : http://ejournal.umm.ac.id/index.php/kembara/article/view/5687.

Rumidjan, Muh. Arafik. 2016. Profil Pembelajaran Unggah-Ungguh Bahasa Jawa Di Sekolah Dasar. Sekolah Dasar, Tahun 25 No. 1 Hal. 55-61. Tersedia Pada : http://journal2.um.ac.id/index.php/sd/article/view/1313/679.

Sudaryanto. 1992. Tata Bahasa Baku Bahasa Jawa. Yogyakarta : Duta Wacana University Press.

Sudiatmanto. 2016. Peningkatan Prestasi Belajar Bahasa Jawa Materi Unggah Ungguh Basa dengan Menerapkan Pembelajaran Kontekstual pada Siswa Kelas VII-E di SMP Negeri 1 Pogalan Trenggalek Semester II Tahun 2012/2013. Jurnal Pendidikan Profesional, Vol. 5 No. 1 Hal. 129136. Tersedia Pada http://www.jurnalpendidikanprofesional.com/index.php/JPP/article/viewFile/133/pdf_73.

Sugiyono. 2016. Metode Penelitian Kuantitatif, Kualitatif dan R\&D. Bandung : Alfabeta.

Sukmadinata. 2016. Metode Penelitian Pendidikan. Bandung : PT Remaja Rosdakarya.

Wulan, Sri Hertanti. 2013. Pembelajaran Bahasa Jawa sebagai Pembentuk Jati Diri Bangsa. Jurnal Kebudayaan Jawa Vol. 1 No. 3 Hal. 1-9. Tersedia Pada : http://staff.uny.ac.id/sites/default/files/penelitian/sri-hertanti-wulan-s-pd-m-hum/artikeljurnal-kejawen-upload.pdf. 